\title{
Scientific and practical aspects of innovative technology of pelleted seeds and their use in the national economy
}

\author{
V.V. Kopytkov* \\ State Scientific Institution "Forest Institute of the National Academy of Sciences of Belarus", Gomel, \\ Republic of Belarus
}

\begin{abstract}
The research results on the pelleted seeds production technology using domestic granulator KVV-14 on the basis of plant polysaccharides were presented. Prospects of using pelleted seeds in the national economy were shown. The best quality indicators of the obtained forest species pelleted seeds were obtained in options using plant polysaccharides of sizes from 350 to $400 \mu \mathrm{m}$, polymer binder and "Nanoplant" microfertilizer. Their mutual use had a positive effect on the quality of pelleted seeds. Sowing of pelleted seeds with a decrease in the seeding rate by $32-33 \% \mathrm{~kg}$ ensures the normative yield of standard forest species seedlings. Developed innovative technology of pelleted forest species seeds production based on domestic pelletizer KVV-14 using plant polysaccharides allows to conduct research with various agricultural seeds, as well as its industrial buildup with subsequent introduction.
\end{abstract}

\section{Introduction}

Pre-sowing seeds' treatment is of great importance in the cultivation of standard forest species seedlings. In recent years, one of the promising ways of pre-sowing seeds treatment is pelleting. Uniform seeding of pelleted forest species seeds eliminates competition during their germination and ensures uniform seedlings' development throughout the entire growing season [1,2]

The pelleting process can be carried out on Dutch or domestic installations using organic, mineral substances and targeted additives [3-5]. Targeted additives influence soil germination of seeds and biometric indicators of seedlings [6,7].

The aim of the research was to develop a technology for producing pelleted seeds based on the use of plant polysaccharides and to obtain standard planting material. To achieve this goal, the following tasks were planned: to conduct research work to identify the most effective components of polymer composition; to investigate physical properties of polymer composition; to determine the forestry efficiency of using pelleted seeds.

\footnotetext{
* Corresponding author: kopvo@mail.ru
} 


\section{Materials and Methods}

Studies of polymer compounds production with various target additives for forest seeds pelleting were carried out using plant polysaccharides of different sizes, polymer binder (NaKMC) and "Nanoplant" microfertilizer. The production of pelleted forest species seeds with various target additives was carried out in laboratory conditions of the Institute of Mechanics of Metal-Polymer Systems of the National Academy of Sciences of Belarus named after V.A. Belyi on KVV-14 unit.

Forestry efficiency of polymer compositions' usage in forest species seedlings' cultivation was determined on the basis of standard research methods considering climatic conditions of the region.

Field studies on the influence of pelleted forest species seeds on biometric seedlings' indices and standard planting material output from 1 ha were carried out in the Mozyrskiy experimental forestry station and in the forest nursery complex with a research station in the city of Kazalinsk. Vegetable polysaccharides of various sizes (from 300 to $600 \mu \mathrm{m}$ ) were used as an organic matter for seeds' pelleting. The polymer of sodium salt carboxymethyl cellulose (5-10 w.\%) and "Nanoplant" microfertilizer (2-3 w.\%) were used for the study. "Nanoplant" microfertilizer contains eight microelements. These nanoparticles have a unique property of hyperpermeability through protective cell membranes, which allows to reduce microelements" consumption hundreds of times and ensure high enzyme synthesis activity, which provide faster growth and development of plants.

The obtained results of laboratory and field studies are processed by methods of mathematical statistics [8].

\section{Research results}

To develop a technology for obtaining pelleted seeds of forest species, it is necessary to investigate the influence of different sizes of plant polysaccharides on granule strength and water absorption.

In laboratory conditions, the influence of different sizes of plant polysaccharides on the physical pelleted seeds indicators of Baltic pine and black saxaul (table 1) has been studied.

As a result of laboratory studies, we have established the optimal physical properties of polymer compositions using plant polysaccharides of $350-400 \mu \mathrm{m}$ size. Increasing the size of plant polysaccharides from 450 to $600 \mu \mathrm{m}$ reduces the water absorption percentage.

Studies on the influence of plant polysaccharide sizes on the strength of pelleted forest species seeds have shown that the greatest optimal indicator was recorded when using plant polysaccharides of 350-400 $\mu \mathrm{m}$ size. Changing the plant polysaccharides' size to a larger or smaller concentration contributes to the deterioration of polymer compositions' physical properties.

Table 1. Influence of plant polysaccharides sizes on physical properties of pelleted forest species' seeds

\begin{tabular}{|l|l|l|l|l|l|l|l|l|}
\hline Parameters under study & \multicolumn{7}{|c|}{ Plant polysaccharides } \\
\hline Particle size, $\mu \mathrm{m}$ & $\begin{array}{l}30 \\
0\end{array}$ & $\begin{array}{l}35 \\
0\end{array}$ & $\begin{array}{l}40 \\
0\end{array}$ & $\begin{array}{l}45 \\
0\end{array}$ & $\begin{array}{l}50 \\
0\end{array}$ & $\begin{array}{l}60 \\
0\end{array}$ \\
\hline \multicolumn{7}{|c|}{ Baltic pine seeds } \\
\hline Water absorption, \% & 44 & 52 & 56 & 50 & 48 & 46 \\
\hline Compressive strength, N & 34 & 29 & 30 & 28 & 26 & 22 \\
\hline \multicolumn{7}{|c|}{ black saxaul seeds } \\
\hline Water absorption, \% & 30 & 35 & 40 & 32 & 34 & 32 \\
\hline Compressive strength, N & 20 & 24 & 26 & 22 & 20 & 18 \\
\hline
\end{tabular}

Based on the calculations, we have established optimal values of polymer composition concentrations for obtaining pelleted forest species seeds (table 2). 
When the pelleted seeds are obtained, a shell is formed on them formed by mixing plant polysaccharides, carboxymethyl cellulose salt and "Nanoplant" microfertilizer. The resulting mixture is fed into a pelletizer, in which it is moistened with water until a homogeneous mass is obtained and mixed with seeds. As a result of gravitational forces, the seeds are enveloped with the resulting moistened mixture [9].

Table 2. Ingredients concentration by response functions $\mathrm{Y}_{1}, \mathrm{Y}_{2}$ in polymer composition

\begin{tabular}{|l|l|}
\hline Polymer composition & Weight \% \\
\hline Plant polysaccharides & $70-80$ \\
\hline Sodium salt carboxymethyl cellulose & $5-10$ \\
\hline "Nanoplant" microfertilizer & $2-3$ \\
\hline Water & other \\
\hline
\end{tabular}

The study of pelleted forest species' seeds production was preceded by the study of their weight and diameter. Analysis of mass and average diameter of black saxaul seeds allowed to establish the following indicators: weight $-2 \mathrm{~g}$ and diameter $-2.0 \mathrm{~mm}$. Similar studies have been carried out to determine the average weight and diameter of Baltic pine seeds. The value of these indicators amounted to: the weight of seeds - $6.9 \mathrm{~g}$ and the average diameter $-5.0 \mathrm{~mm}$.

Mathematical analysis of forest species' seeds weight and polymer compositions allowed to establish that the standard quadratic deviation of the polymer composition weight and the total seeds weight fluctuate: Baltic pine seeds - 0,384-0,41, black saxaul $0,54-0,32$ (table 3 ).

Table 3. Biometric parameters of pelleted seeds

\begin{tabular}{|l|l|l|l|l|l|}
\hline $\begin{array}{l}\text { Seeds weight and } \\
\text { polymer } \\
\text { composition }\end{array}$ & $\begin{array}{l}\text { Mean, } \\
\mathrm{M}\end{array}$ & $\begin{array}{l}\text { Standard } \\
\text { quadratic } \\
\text { deviation, } \\
\sigma\end{array}$ & $\begin{array}{l}\text { Standard } \\
\text { error, mM }\end{array}$ & $\begin{array}{l}\text { Precision } \\
\text { percentage, \% }\end{array}$ & $\begin{array}{l}\text { Variation } \\
\text { coefficient, } \\
\text { vo }\end{array}$ \\
\hline \multicolumn{5}{|c|}{ Pine seeds } \\
\hline Seeds weight, g & 6.9 & 0.41 & 0.18 & 2.1 & 5.2 \\
\hline $\begin{array}{l}\text { Weight of } \\
\text { polymer } \\
\text { composition, g }\end{array}$ & 18.2 & 0.38 & 0.18 & 0.9 & 2.0 \\
\hline \multicolumn{5}{|l|}{ Saxaul seeds } \\
\hline $\begin{array}{l}\text { Seeds weight, g } \\
\text { Weight of } \\
\text { polymer } \\
\text { composition, g }\end{array}$ & 6.1 & 0.32 & 0.06 & 1.3 & 1.3 \\
\hline
\end{tabular}

When growing standard planting material, balanced nutrition of plants with nutritional elements is crucial. The use of "Nanoplant" microelements contributes to increasing the growing efficiency of forest species' seedlings.

When growing planting material in open ground conditions, the rate seeds' sowing is of great influence on the output of standard forest species seedlings. Table 4 presents the obtained field study results on the influence of the forest species sowing norm on the seedlings' height of the above-ground part and the diameter of the root neck. 
Table 4. The height of the above-ground part and the diameter of the root neck of the forest planting material

\begin{tabular}{|c|c|c|c|}
\hline $\begin{array}{l}\text { Sowing of regular and } \\
\text { pelleted seeds, } \mathrm{kg} / \mathrm{ha}\end{array}$ & Stem height, cm & $\begin{array}{l}\text { Root neck } \\
\text { diameter, } \mathrm{mm}\end{array}$ & $\begin{array}{l}\text { Output of standard } \\
\text { seedlings, } \\
\text { M.pcs./ha }\end{array}$ \\
\hline \multicolumn{4}{|c|}{ Pine seeds } \\
\hline $\begin{array}{l}\text { Sowing rate - } \\
\text { accordance with } \\
\text { "Instruction..." }[10]\end{array}$ & $5.2 \pm 0.17$ & $2.0 \pm 0.05$ & $2.2 \pm 0.11$ \\
\hline $\begin{array}{l}\text { Pelleted seeds sowing } \\
\text { rate - in accordance with } \\
\text { the "Instruction..." - }\end{array}$ & $8.5 \pm 0.21$ & $2.2 \pm 0.05$ & $2.4 \pm 0.26$ \\
\hline Pelleted seeds - $45 \mathrm{~kg} / \mathrm{ha}$. & $9.2 \pm 0.17$ & $2.3 \pm 0.02$ & $2.6 \pm 0.23$ \\
\hline \multicolumn{4}{|c|}{ Saxaul seeds } \\
\hline $\begin{array}{l}\text { Sowing rate - in } \\
\text { accordance with the } \\
\text { "Recommendations..." } \\
\text { [11] }\end{array}$ & $20.1 \pm 0.19$ & $2.5 \pm 0.06$ & $0.34 \pm 0.04$ \\
\hline $\begin{array}{l}\text { The rate of pelleted seeds } \\
\text { sowing - in accordance } \\
\text { with } \\
\text { "Recommendations..." }\end{array}$ & $24.4 \pm 0.26$ & $2.8 \pm 0.09$ & $0.42 \pm 0.06$ \\
\hline Pelleted seeds - $45 \mathrm{~kg} / \mathrm{ha}$. & $26.3 \pm 0.29$ & $3.1 \pm 0.08$ & $0.45 \pm 0.07$ \\
\hline
\end{tabular}

The analysis of this table shows that the above-ground part height of Baltic pine and saxaul black seedlings depends on the forest seeds' sowing rate. When sowing pelleted Baltic pine seeds in accordance with the "Instruction..." [10] $(60 \mathrm{~kg} / \mathrm{ha})$, the height of the above-ground seedlings part is higher by $63 \%$, and the diameter of the root neck - by $10 \%$. The standard seedlings output of the Baltic pine on this experimental option exceeded the control by $9 \%$. Reduction of the Baltic pine pelleted seeds' sowing norm by 1.3 times or by $33 \%$ ensures the normative yield of standard seedlings with a well-developed above-ground part. A similar pattern can be traced in pelleted black saxaul seeds' sowing.

\section{Conclusion}

Analysis of the obtained research results shows that the most promising way of forest species seeds' pre-sowing treatment is pelleting.

The optimum concentration of ingredients was established as follows: plant polysaccharides (70-80 w.\%), sodium salt carboxymethyl cellulose $(5-10 \quad$ w.\% $)$, "Nanoplant" microfertilizer (2- 3 w.\%), water - the rest.

With a decrease in the seeding rate of pelleted seeds by $32-33 \%$, the normative yield of standard forest species' seedlings is ensured. Seedlings' biometric indicators when using pelleted seeds are $10-63 \%$ higher than the control option.

Analyzing the obtained physical properties data of experimental pelleted seeds batches, the optimal pellets' strength for the Baltic pine seeds was 29-30 N, and for black saxaul 24-26 N. This shell strength is not destroyed by the seeders' sowing apparatus and has good 
water absorption capacity and solubility in the soil, as well as a stimulating effect on biometric seedlings' indicators.

The developed innovative technology of pelleted forest species seeds' production based on domestic KVV-14 unit using plant polysaccharides allows to conduct research with various agricultural seeds, as well as industrial buildup with subsequent introduction.

\section{References}

1. V.D. Mukhin, Seeds pelleting of agricultural crops (M: Kolos, 95, 1971)

2. A. Holland Mark, Seeds, coated or impregnated with a PPFM: Pat. 5512069 USA, MPK7 A 01 C 1/06, applicant, Salisbary State University (1996)

3. D. A. Mikheev, Pelleting of sugar beet seeds with centrifugal pelletizer with lobed reflector, 180 (2017)

4. N. A. Lukyanyuk, Coll. of scient. works, 52, 105-107 (1999)

5. E.G. Paramonov, Bulletin of the Altai Agrarian University, 8 (106), 48-50 (2013)

6. Guiming Zhu, Li Jun; Zhenming Cong. Pumpkin seed granulator: pat. CN201755846, Publ. date 09.03.2011

7. A.B. Spiridonov, V.V. Kasatkin, M.A. Vyguzova, N.V. Ovsyannikov, T.S. Kopysova, Method of flax seeds pelleting: Pat. RU 2633540, Publ. 13.10.2017

8. G.N. Zaitsev, Mathematical statistics in experimental botany (M: Nauka, 424, 1984) (in Russian)

9. V.V. Kopytkov, Method of obtaining pelleted seeds: pat. No.15084 Rep. of Belarus MPK (2009) A 01C 1/06, 6 (83), 53 (2010)

10. TKP 575-2015/PR1. Instruction on planting material cultivation of wood and shrubby species in forest nurseries of the Republic of Belarus, 60 (2015)

11. Recommendations for growing planting material in forest irrigation nurseries, Astana, 12 (2014) 